\title{
Pentastomids infecting an invader lizard, Hemidactylus mabouia (Gekkonidae) in northeastern Brazil
}

\author{
Anjos, LA. ${ }^{\mathrm{a}}$, Almeida, WO. ${ }^{\mathrm{b} *}$, Vasconcellos, A. ${ }^{\mathrm{c}}$, Freire, EMX. ${ }^{\mathrm{c}}$ and Rocha, CFD. ${ }^{\mathrm{a}}$ \\ a'Departamento de Ecologia, Universidade do Estado do Rio de Janeiro - UERJ, \\ Rio de Janeiro, RJ, Brazil \\ bDepartamento de Ciências Físicas e Biológicas, Universidade Regional do Cariri - URCA, \\ Rua Cel. Antônio Luiz, 1161, CEP 63105-000, Crato, CE, Brazil \\ 'Departamento de Botânica, Ecologia e Zoologia, Universidade Federal do Rio Grande do Norte - UFRN, \\ Natal, RN, Brazil \\ *e-mail: walmeida@urca.br \\ Received September 13, 2006 - Accepted November 20, 2006 - Distributed August 31, 2008
}

(With 1 figure)

\begin{abstract}
From January to April 2006, 37 specimens of Hemidactylus mabouia were collected in houses, in the municipality of Barbalha ( $7^{\circ} 20^{\prime} \mathrm{S}$ and $39^{\circ} 18^{\prime} \mathrm{W}$ ), Ceará State, Northeast Brazil. Among the individuals captured, 17 were infected with pentastomids, totalling a prevalence of $45.9 \%$, which did not differ between sexes. Host size did not influence the infection intensity. Two species of pentastomids were found: Raillietiella frenatus and $R$. mottae. The prevalence of $R$. frenatus $(43.2 \%)$ was higher than $R$. mottae (2.7\%), whereas the infection intensity of $R$. frenatus was comparatively lower $(1.8 \pm 1.4)$ than $R$. mottae (36 parasites in a single host). Overall mean intensity of infection was $3.8 \pm 8.4$ pentastomids. We found no pentastomid infecting juvenile geckos. The parameters of infection in this host population are in accordance to the findings of other studies, in which the high parasitism rate was associated to the feeding habits of geckos living in houses and buildings. Hemidactylus mabouia is a new host to $R$. mottae and the infection by $R$. frenatus is the first record of the occurrence this pentastomid species in Brazil.
\end{abstract}

Keywords: Raillietiella, Pentastomida, house geckos, neotropical region.

\section{Pentastomídeos infectando um lagarto invasor, Hemidactylus mabouia (Gekkonidae), na região nordeste do Brasil}

\section{Resumo}

De janeiro a abril de 2006 foram coletados 37 espécimes de Hemidactylus mabouia em domicílios no município de Barbalha ( $7^{\circ} 20^{\prime} \mathrm{S}$ e $\left.39^{\circ} 18^{\prime} \mathrm{W}\right)$, Estado do Ceará, Nordeste do Brasil. Entre os indivíduos capturados, 17 estavam infectados com pentastomídeos, totalizando uma prevalência de 45,9\%, sem diferenças significantes entre os sexos. O tamanho dos hospedeiros também não influenciou na intensidade de infecção. Duas espécies de pentastomídeos foram encontradas: Raillietiella frenatus e $R$. mottae. A prevalência de $R$. frenatus $(43,2 \%)$ foi mais alta do que a de $R$. mottae $(2,7 \%)$, enquanto que a intensidade média de infecção de $R$. frenatus foi comparativamente mais baixa $(1.8 \pm 1.4)$ do que a de $R$. mottae (36 parasitas em um único indivíduo). A intensidade geral de infecção foi de $3.8 \pm 8.4$ pentastomídeos. Não foi encontrado nenhum gecko juvenil infectado por pentastomídeo. Os parâmetros de infecção nesta população de hospedeiros estão de acordo com outros estudos, que indicam altas taxas de parasitismo associadas com os hábitos alimentares de geckos vivendo em domicílios e edificações. Hemidactylus mabouia representa um novo hospedeiro para $R$. mottae e a infecção por $R$. frenatus constitui o primeiro registro de ocorrência desta espécie de pentastomídeo no Brasil.

Palavras-chave: Raillietiella, Pentastomida, geckos domiciliares, região neotropical.

\section{Introduction}

Some invader lizards of the genus Hemidactylus (Gekkonidae) have contributed to the decrease and extinction of native lizard fauna in different regions of the planet (Selcer, 1986; Dixon, 1987; Riley et al., 1988; Criscione and Font, 2001). The gecko Hemidactylus mabouia is a broadly distributed species in the tropics which invaded the New World after accidental introductions, becoming a successful colonizer widely represented in southern North America and in Central and South America (Federico and Cacivio, 2000).

Throughout its range, H. mabouia has harboured an extensive parasitic fauna composed of protozoans, platy- 
helminthes, acanthocephalans, nematodes, pentastomids, and mites (Ali et al., 1985; Simonsen and Sarda, 1985; Lainson and Paperna, 1999; Martínez-Rivera et al., 2003). However, few studies have been performed to evaluate to what extent this parasitic fauna was 'left behind' during the colonization process or if a subset of it was carried with their invader hosts. Recent studies have shown that Hemidactylus turcicus and H. mabouia have played a minor role in the introduction of their exotic parasites, indeed that exotic hosts have been colonized by native fauna of parasites, as reported by Vicente et al. (1993); Hanley et al. (1995); Criscione and Font (2001); Anjos et al. (2005). However, one parasite mite, Geckobia hemidactyli, seems to have accompanied H. mabouia throughout its dispersion towards the western (MartínezRivera et al., 2003).

Pentastomids are common parasites of the respiratory tract of vertebrates, with more than 130 species described (Almeida and Christoffersen, 1999; 2002; Rego, 1983; 1984). Knowledge on infection by the pentastomid Raillietiella on geckos in the Americas is scarce, although the African pentastomids Raillietiella frenatus and $R$. teagueselfi were reported in the lungs of the exotic gecko Hemidactylus turcicus in Texas and Florida (USA) (Pence and Selcer, 1988; Riley et al., 1988; 1991). In Central America there has been only one report of pentastomid in the lungs of $\mathrm{H}$. mabouia (formerly identified as $R$. frenatus) in Puerto Rico (Self and Diaz, 1961). In Brazil, few works concerning raillietiellids as lizard parasites have been reported: Raillietiella freitasi in the lungs of Thrachylepis atlanticus (formerly Mabuya punctata), from Fernando de Noronha Island (situated on the northeastern coast) (Motta, 1963; Motta and Gomes, 1968; Rego, 1983; 1984); larvae of Raillietiella sp. in skink Mabuya agilis reported by Vrcibradic et al. (2002); Dias et al. (2005) reported a likely new species of Raillietiella aff. furcocerca infecting Cnemidophorus abaetensis and Cnemidophorus ocellifer; and Almeida et al. (2008) described R. mottae living in the lungs of Tropidurus hispidus, a dweller of Cariri (a microregion of Ceará State).

In this study we evaluate pentastomid infection in a population of the exotic gecko $H$. mabouia living in an urban area in northeastern Brazil, specifically addressing: i) what is the composition of pentastomid fauna; and ii) to what extent do the host sex and size affect the parameters of infection (prevalence and intensity) by pentastomids.

\section{Material and Methods}

We collected 37 specimens of Hemidactylus mabouia from January through April 2006 in human buildings (houses) in the municipality of Barbalha $\left(7^{\circ} 18^{\prime} \mathrm{S}\right.$ and $39^{\circ} 18^{\prime}$ W, Figure 1), southern Ceará state, in Northeastern Brazil. The climate of the area is predominantly mild hot semi-arid, with a mean annual temperature varying from 24 to $26{ }^{\circ} \mathrm{C}$ and an annual rainfall of $1153 \mathrm{~mm}$, with

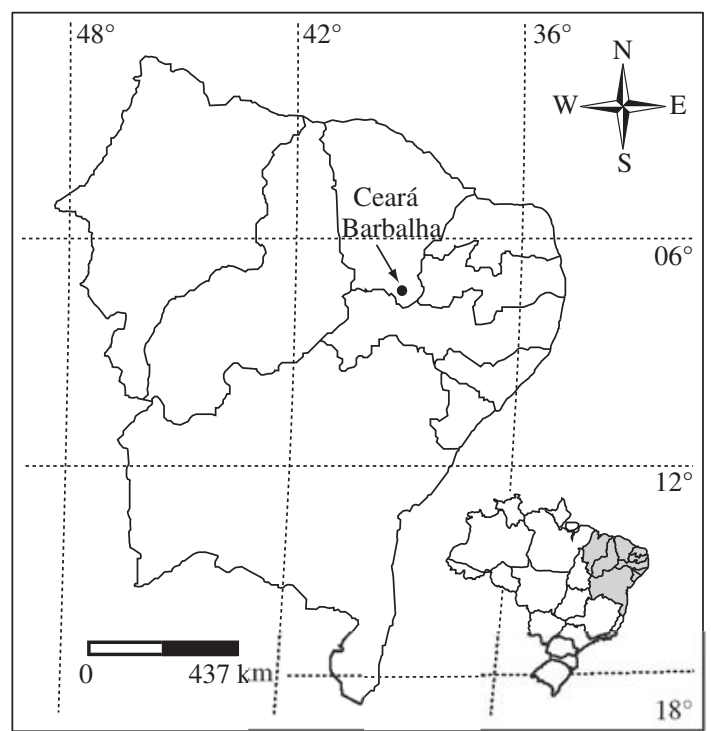

Figure 1. Location of the study area in Northeastern Brazil. The municipality of Barbalha (Ceará) is indicated by the black dot.

a marked rainy period from January to April and a dry season from May to December. The vegetation in the area is composed of plant species common to Caatinga, Cerrado, wet forest, and transitional zones between these adjacent biomes (IPECE, 2005).

Lizards were collected by hand, being promptly euthanized with ether and fixed with formalin $10 \%$ and posteriorly preserved in ethanol $70 \%$. Lizard snoutvent length (SVL) was measured with a ruler (to the nearest $1 \mathrm{~mm}$ ). Voucher specimens were housed in the Zoological Collection of the Universidade Regional do Cariri (LZ-URCA): 323-332, 334, 336, 338, 339, 341-355, 368-375.

We removed the lungs of the geckos which were carefully checked under a stereomicroscope to search for pentastomids. The pentastomids found were either preserved in ethanol $70 \%$ or mounted on slides and treated with a Hoyer medium. Their identification was based on the dimension of hooks and the copulatory spicules of males (Rego, 1983; 1984; Ali et al., 1981; 1984a, b, 1985). The specimens found were compared with representative material from two collections: the Helminthological Collection of the Instituto Oswaldo Cruz (CHIOC) and the Zoological Collection of the Laboratory of the Universidade Regional do Cariri (LZ-URCA) in order to confirm parasite identity: Raillietiella freitasi (CHIOC 20420, 20421, 20429, 20431, 20432, 20434, 20439, 30325a-c, 30326, 30327, 30328, 30329a-c, 30330a-b) and $R$. mottae (LZ-URCA 0201-212).

The ecological terms in parasitology used in the present study follow Bush et al. (1997). A $t$-test was performed to evaluate if there was a significant difference between size (SVL) of hosts and to test for sexual differ- 
ences in adult lizards in terms of intensity of infection. Sexual differences in overall prevalence were tested using the Z-test for proportions (Zar, 1999). The effect of lizard host size (SVL in $\mathrm{mm}$ ) on pentastomid lung infection rate was analysed using the Spearman rank correlation (Zar, 1999). For the estimates of the relationship between host size (SVL in $\mathrm{mm}$ ) and intensity of infection, only the hosts parasitized by $R$. frenatus were included, because of the greater prevalence of this parasite and also due to the possibility of misunderstanding the interpretation of results due to the occurrence of an 'outlier' (a highly infected female - see below).

\section{Results}

We sampled a total of 37 geckos, being 10 juveniles (mean SVL $=30.2 \pm 7.5 \mathrm{~mm}$; range $=17.0-38.0 \mathrm{~mm}$ ), 11 adult females (mean SVL $=58.5 \pm 4.3 \mathrm{~mm}$; range $=52.0-65.0 \mathrm{~mm}$ ), and 16 adult males (mean $\mathrm{SVL}=55.6 \pm 6.0 \mathrm{~mm} ;$ range $=48.0-65.0 \mathrm{~mm})($ Table 1$)$. The sexes of the lizard did not differ significantly in terms of SVL ( $t$-test: $\mathrm{t}=1.395 ; \mathrm{df}=25 ; \mathrm{p}=0.175$ ). However, adult and juvenile geckos differed significantly in SVL $(\mathrm{t}=11.918 ; \mathrm{df}=35 ; \mathrm{p}<0.001)$.

We found only two species of Pentastomida infecting H. mabouia: Raillietiella frenatus and $R$. mottae, which were infecting the lungs of lizards. These are the first records of occurrence of the pentastomids $R$. frenatus in Brazil, and H. mabouia is a new host to R. mottae. Of the 37 geckos analyzed, 17 individuals were parasitized by at least one species of pentastomid (overall prevalence of $45.9 \%$, Table 1). The overall prevalence in adult females was $54.5 \%$ (6/11; Table 1) whereas within adult males, it was $68.8 \%$ (11/16; Table 1$)$, but the differences among adults of the sexes was not significant (Z-test: $Z_{c}=0.34$; $p=0.730$ ). We found no pentastomid infecting juvenile geckos.

The mean intensity of infection of $R$. frenatus was $1.8 \pm 1.4$ pentastomids (Table 1 ), whereas the infection rate of a single female infected by $R$. mottae was 36 parasites (Table 1). Overall mean intensity of infection was $3.8 \pm 8.4$ pentastomids (Table 1). Mean intensity of infection by $R$. frenatus did not differ significantly ( $t$-test: $\mathrm{t}=1.164 ; \mathrm{df}=14 ; \mathrm{p}=0.264)$ between adult females $(2.4 \pm 1.9$; Table 1$)$ and adult males $(1.5 \pm 1.0$; Table 1$)$.
The size of adult host lizards (SVL) did not influence the intensity of infection $\left(r_{s}=0.489 ; p=0.055 ; n=16\right)$, but this result could be due to the low number of female hosts $\left(r_{\mathrm{s}}=0.229 ; \mathrm{p}=0.710 ; \mathrm{n}=5\right)$.

\section{Discussion}

From a historical perspective, $R$. frenatus probably followed the colonization movements of Hemidactylus spp. (Self and Diaz, 1961; Riley et al., 1991) whereas $R$. mottae seems to have been acquired in the New World, from a native lizard species, T. hispidus (Almeida et al., 2008).

The overall prevalence (45.9\%) of pentastomids infecting the studied population of $H$. mabouia was markedly lower than those reported for $H$. mabouia from Puerto Rico (89\%; Simonsen and Sarda, 1985) and for $H$. haitianus from the Caribbean Hispaniola Island (62\%; Powell et al., 1993), but they were higher than $H$. turcicus from the United States (19.8\%; Riley et al., 1988 ) and $H$. frenatus from Indonesia (25-33\%; Matsuo and Oku, 2002). In Brazil, the studies have shown unequal prevalence in native lizards species Mabuya agilis (3.6-9.0\%; Vrcibradic et al., 2002); Cnemidophorus abaetensis (6.0\%; Dias et al., 2005), and C. ocellifer (2.5\%; Dias et al., 2005); and Tropidurus hispidus (11.1\%; Almeida et al., 2008).

Juvenile $H$. mabouia lizards were not infected by pentastomids. This may result from the fact that larger and probably older geckos tend to present a greater diversity of parasites, prevalence, and mean intensity of infection due to the comparatively longer time of exposition and contact with infection sources (Vogel and Bundy, 1987; Cunha-Barros et al., 2003). The diet composition of hosts also could influence these infection parameters (Rocha, 1989; Vitt, 2000; Anjos et. al., 2005). The diet of host $H$. mabouia juveniles usually includes only ants and termites; whereas the stomachs of adult individuals contain various types of arthropods, including larger items such as spiders, cockroaches, and moths (Almeida, present data; Rocha and Anjos, 2007). We do not know to what extent such ontogenetic differences in diet composition may favour the absence of pentastomid parasites in juvenile geckos of the population studied here.

Table 1. Snout-vent length (mm) \pm standard Deviation, Overall Prevalence (\%) and Intensity of infection by Raillitiella frenatus and R. mottae in Hemidactylus mabouia from Barbalha municipality, Brazil.

\begin{tabular}{|c|c|c|c|c|c|c|c|c|}
\hline \multirow[t]{3}{*}{ Host } & \multirow[t]{3}{*}{ SVL (mm) } & \multirow[t]{3}{*}{$\mathbf{N}$} & \multicolumn{4}{|c|}{ Parasite species } & \multicolumn{2}{|c|}{ Overall } \\
\hline & & & \multicolumn{2}{|c|}{ Raillietiella frenatus } & \multicolumn{2}{|c|}{ Raillietiella mottae } & & \\
\hline & & & $\begin{array}{c}\text { Prevalence } \\
(\%)\end{array}$ & $\begin{array}{c}\text { Intensity of } \\
\text { Infection }\end{array}$ & $\begin{array}{c}\text { Prevalence } \\
(\%)\end{array}$ & $\begin{array}{c}\text { Intensity of } \\
\text { Infection }\end{array}$ & $\begin{array}{c}\text { Prevalence } \\
(\%)\end{array}$ & $\begin{array}{c}\text { Intensity of } \\
\text { Infection }\end{array}$ \\
\hline Males & $55.6 \pm 6.0$ & 16 & 68.80 & $1.5 \pm 1.0$ & 0.0 & - & 68.8 & $1.5 \pm 1.0$ \\
\hline Females & $58.5 \pm 4.3$ & 11 & 45.4 & $2.4 \pm 1.9$ & 9.1 & 36 & 54.5 & $8.0 \pm 13.8$ \\
\hline Juveniles & $30.2 \pm 7.5$ & 10 & 0.0 & - & 0.0 & - & 0.0 & - \\
\hline Total & - & 37 & 43.2 & $1.8 \pm 1.4$ & 2.7 & 36 & 45.9 & $3.8 \pm 8.4$ \\
\hline
\end{tabular}


Raillietiella mottae was found in just one individual lizard host (low prevalence, $2.7 \%$ ) with high infection intensity (36 pentastomids). The mean intensity of infection by Raillietiella frenatus $(1.8 \pm 1.4)$ was similar to other mean intensity values reported for other pentastomids species in Brazil and some other lizard hosts in natural infections: $1.0 \pm 0.0$ in Mabuya agilis (Vrcibradic et al., 2002); $4.5 \pm 0.0$ in Cnemidophorus abaetensis (Dias et al., 2005); $1.0 \pm 0.0$ in C. ocellifer (Dias et al., 2005); and $6.0 \pm 1.4$ in Tropidurus hispidus (Almeida et al., 2008). However, a single host female parasitized by $R$. mottae presented a high intensity of infection (36 parasites) as compared with all the abovementioned other host data. We are fully aware that our small sampling does not enable us to make generalizations about the high degree of infection and consequent damage caused by $R$. mottae in H. mabouia in Brazil.

Although the prevalence between males $(68.8 \%)$ and females (54.5\%) did not differ, the infection intensity was higher in females $(2.4 \pm 1.9)$ than in males $(1.5 \pm 1.0)$. Since males and females did not differ in size, diet and habitat use, as we observed in situ, this could explain the similar prevalence between males and females. However, the difference in infection rates between males and females could be explained by inherent factors.

In Gekkonidae, particularly in house dweller species, their egg-contaminated faeces and prey items (such as cockroaches) usually result in very high prevalence and intensity of pentastomid infection (Ali and Riley, 1983; Riley et al., 1991). Thus, such trophic relationship of house geckos may explain in part the relative difference between the infection rates of H. mabouia and other sympatric lizards in northeast Brazil and very likely in other regions of this country.

It has been demonstrated experimentally that $R$. frenatus may utilize cockroaches as intermediate hosts (Ali and Riley, 1983; Jeffery et al., 1985; Bosch, 1986). The success in associating to new intermediate hosts might have been the keystone for $R$. frenatus to maintain itself in exotic hosts and would be favored due to widely distributed intermediate hosts like cockroaches (Criscione and Font, 2001).

Pentastomids have shown to be regulator parasites of lizard populations (Riley et al., 1991). The way exotic pentastomids act on native lizards and their potential host regulatory capacity upon exotic gecko populations deserves further studies. Our understanding of these questions may contribute to the adaptive success and establishment of this exotic lizard and consequently its regulatory process.

Acknowledgements - We thank D. Noronha, curator of the Helminthological Collection of the Instituto Oswaldo Cruz, for the loan of pentastomid specimens. The authors acknowledge a research grant received from FUNCAP - Fundação Cearense de Apoio ao Desenvolvimento Científico e Tecnológico ('Ref. 943/03 - Edital 003/03). We are also grateful to IBAMA - the Brazilian Institute for the Environment and Natural Resources for their permission to collect samples from protection areas (processes \# 02021.000075/ 2006-7; \# 080/ 04 - RAN/ IBAMA 02007.001009/ 04-73); C.F.D. Rocha received research grants from CNPq (processes $n^{\circ} 477981 / 2003-8$ and 307653/03-0). Thanks are also due to D. Vrcibradic (UERJ) and one anonymous reviewer for valuable suggestions and criticisms on the manuscript, and to B. Grisi for suggestions and the English version of the manuscript.

\section{References}

ALI, JH. and RILEY, J., 1983. Experimental life-cycles studies of Raillietiella gehyrae Bovien, 1927 and Raillietiella frenatus Ali, Riley and Self, 1981: pentastomid parasites of geckos utilizing insects as intermediate hosts. Parasitology, vol. 86, p. $147-160$.

ALI, JH., RILEY, J. and SELF, JT., 1981. A revision of the taxonomy of the blunt-hooked Raillietiella, pentastomid parasites of African, South-East-Asian and Indonesian lizards, with a description of a new species. Syst. Parasitol., vol. 3, no. 4 , p. $193-207$.

-, 1984a. A revision of the taxonomy of pentastomid parasites (genus Raillietiella Sambon, 1910) from American snakes and amphisbaenias. Syst. Parasitol., vol. 6, no. 2, p. 87-97.

-., 1984b. Further observations of blunt-hooked raillietiellids (Pentastomida: Cephalobaenida) from lizards with descriptions of three new species. Syst. Parasitol., vol. 6, no. 2, p. 147-160.

-, 1985. A review of the taxonomy and systematics of the pentastomids genus Raillietiella Sambon, 1910 with a description of a new species. Syst. Parasitol., vol. 7, no. 2, p. 111-123.

ALMEIDA, WO. and CHRISTOFFERSEN, ML., 1999. A cladistic approach to relationships in Pentastomida. J. Parasitol., vol. 85 , no. 4 , p. $695-704$.

-., 2002. Pentastomida. In MORRONE, J. and LLORENTEBOUSQUETS, J. (Eds.). Biodiversidad, Taxonomía y Biogeografía de Artrópodos de México: Hacia una síntesis de su conocimiento. México: Universidad Nacional Autónoma de México. p. 187-202.

ALMEIDA, WO., FREIRE, EMX. and LOPES, SG., 2008. A new species of Pentastomida infecting Tropidurus hispidus (Squamata: Tropiduridae) from caatinga in Northeastern Brazil. Rev. Bras. Biol. = Braz. J. Biol., vol. 68, no. 1, p. 199-203.

ANJOS, L., ROCHA CFD., VRCIBRADIC, D. and VICENTE, JJ., 2005. Helminths of exotic lizard Hemidactylus mabouia from a rock outcrop area in southeastern Brazil. J. Helmint., vol. 79 , no. 4 , p. 307-313.

BOSCH,H., 1986. Experimental life-cycle studies of Raillietiella Sambon, 1910 (Pentastomida: Cephalobaenida): The fourth stage larva is infective for the definitive host. Parasitol. Res., vol. 72 , no. 5 , p. 673-680.

CRISCIONE, CD. and FONT, WF., 2001. The guest playing host: colonization of the introduced Mediterranean gecko, Hemidactylus turcicus, by helminth parasites in southeastern Louisiana. J. Parasitol., vol. 87, no. 6, p. 1273-1278.

CUNHA-BARROS, M., VAN SLUYS, M., VRCIBRADIC, D., GALDINO, CAB., HATANO, FH. and ROCHA, CFD., 2003. Patterns of infestation by chigger mites in four diurnal lizard species from a restinga habitat (Jurubatiba) of Southeastern Rev. Bras. Biol. = Braz. J. Biol., vol. 63, no. 3, p. 393-399. 
DIAS, EJR., VRCIBRADIC, D. and ROCHA CFD., 2005. Endoparasites infecting two species of whiptail lizards (Cnemidophorus abaetensis and C. ocellifer; Teiidae) in a restinga habitat of northeastern Brazil. Herpetol. J., vol. 15, no. 2, p. 133-137

DIXON, JR., 1987. Amphibians and repitiles of Texas. Texas: Texas and M University Press, College Station. 434 p.

FEDERICO, L. and CACIVIO, PM., 2000. Hemidactylus mabouia (Tropical Gecko) Geografic Distribution. Herp. Rev., vol. 31 , no. $1,53 \mathrm{p}$.

HANLEY, KA., VOLLMER, DM. and CASE, TJ., 1995. The distribution and prevalence of helminths, coccidian and blood parasites in two competing species of gecko: implications for apparent competition. Oecologia, vol. 102, no. 2, p. 220-229.

IPECE - Instituto de Pesquisa e Estratégia Econômica do Ceará, 2005. Perfil básico municipal: Barbalha. Fortaleza: Governo do Estado do Ceará, Secretaria do Planejamento e Coordenação.

JEFFERY, J., KRISHNASAMY, M., OOTHUMAN, P., ALI, JH., BAKAR, EA. and SINGH, I., 1985. Preliminary observations on the cockroach intermediate host of a house gecko raillietiellid in peninsular Malaysia. Malay. J. Med. Lab. Sci., vol. 2, no. 2, p. 82-84

LAINSON, R. and PAPERNA, I., 1999. Re-descriptions of Isospora ameivae Carini, 1932 in the teiid lizard Ameiva ameiva and Isospora hemidactyli Carini, 1936 in the gecko Hemidactylus mabouia, with particular reference to their endogenous stages. Mem. Inst. Oswaldo Cruz, vol. 94, no. 4, p. 459-466.

MARTÍNEZ-RIVERA, CC., NEGRO, AG., BERTRAND, M. and COSTA, J., 2003. Hemidactylus mabouia (Sauria: Gekkonidae), Host of Geckobia hemidactyli (Actinedida: Pterygosomatidae), throughout the Caribbean and South America. Carib. J. Sci., vol. 39, no. 3, p. 321-326.

MATSUO, K. and OKU, Y., 2002. Endoparasites of three species of house geckos in Lampung, Indonesia. J. Helmint., vol. 76 , no. 1 , p. $53-57$

MOTTA, CS., 1963. Considerações sobre o gênero Raillitiella Sambon, 1910. Atas Soc. Biol. Rio de Janeiro, vol. 7, no. 2, p. $8-10$.

MOTTA, CS. and GOMES, DC., 1968. Sobre um novo gênero e uma nova espécie de Cephalobaenidae (Linguatulida, Cephalobaeniformia). Atas Soc. Biol. Rio de Janeiro, vol. 12, no. 1, p. $7-9$.

PENCE, DB. and SELCER, KW., 1988. Effects of pentastomid infection of reproduction in a southern Texas population of Mediterranean gecko, Hemidactylus turcicus. Copeia, vol. 1988 , no. 3 , p. $565-572$.

POWELL, R., HALL, PJ., SMITH, DD. and RILEY, J., 1993. The occurrence of Raillietiella sp. (Pentastomida: Cephalobaenida) in Hemidactylus haitianus (Lacertilia: Gekkonidae) from Hispaniola. Dactylus, vol. 2, p. 51-53.
SIMONSEN, PE. and SARDA, RK., 1985. Helminth and arthropod parasites of Hemidactylus mabouia from Tanzania. J. Herpetol., vol. 19, no. 3, p. 428-430.

REGO, AA., 1983. Pentastomídeos de répteis do Brasil: Revisão dos Cephalobaenidae. Mem. Inst. Oswaldo Cruz, vol. 78, no. 4, p. $399-411$.

-, 1984. Sinopse dos pentastomídeos da região neotropical. Garcia de Orta, Sér. Zool., Lisboa, vol. 11, no. 1-2, p. 45-56.

RILEY, J., MCALLISTER, C. and FREED, PS., 1988. Raillietiella teagueselfi n sp (Pentastomida: Cephalobaenida) from the mediterranean gecko, Hemidactylus turcicus (Sauria: Gekkonidae), in Texas. J. Parasitol., vol. 74, no. 3, p. 481-486.

RILEY, J., POWELL, R. and SMITH, DD., 1991. Further observations of blunt-hooked pentastomids belonging to the genus Raillietiella Sambon, 1910 infecting Hemidactylus brookii (Sauria: Geckonidae) in Africa and the Caribbean; comparison with closely related Raillietiella spp. from an African skink (Mabuya perrotetii). Syst. Parasitol., vol. 20, no. 1, p. 47-57.

ROCHA, CFD., 1989. Diet of a tropical lizard (Liolaemus lutzae) of southeastern Brazil. J. Herpetol., vol. 23, no. 3, p. $292-294$

ROCHA, CFD. and ANJOS, LA., 2007. Feeding Ecology of a Nocturnal Invasive Alien Lizard Species, Hemidactylus mabouia (Gekkonidae), living in an outcrops rocky area in southeastern Brazil. Rev. Bras. Biol. = Braz. J. Biol., vol 67 , no. 3 , p. $485-491$

SELCER, KW., 1986. Life history of a successful colonizer: The Mediterranean gecko, Hemidactylus turcicus, in southern Texas. Copeia, vol. 1986, no. 4, p. 956-962.

SELF, JT. and DIAZ, JG., 1961. Raillietiella (Heymonsia) hemidactyli Hett, 1934, from Hemidactylus mabouia in Puerto Rico, with a correction of the identity of $R$. hebithamata Self and Kuntz, 1960. J. Parasitol., vol. 47, no. 6, p. 912.

VICENTE, JJ., RODRIGUES, HO., GOMES, DC. and PINTO, RM., 1993. Nematóides do Brasil, parte III: Nematóides de Répteis. Rev. Bras. Zool., vol. 10, no. 1, p. 19-168.

VITT, LJ., 2000. Ecological consequences of body size in neonatal and small-bodied lizards in the neotropics. Herpet. Mon., vol. 14 , no. 1, p. 388-400.

VRCIBRADIC, D., ROCHA, CFD., BURSEY, CD. and VICENTE, JJ., 2002. Helminth communities of two sympatric skinks (Mabuya agilis and Mabuya macrorhyncha) from two 'restinga' habitats in southeastern Brazil. J. Helminthol., vol. 76 , no. 4 , p. 355-361.

VOGEL, P. and BUNDY, DAP., 1987. Helminth parasites of Jamaican anoles (Reptilia: Iguanidae): variation in prevalence and intensity with host age and sex in population of Anolis lineatopus. Parasitology vol. 94, no. 2, p. 399-404.

ZAR, JH. 1999. Biostatistical Analysis. 4 ed. Upper Saddle River: Prentice-Hall. 663 p. 